\title{
67 感染管理における小型全自動熱水消毒洗翟乾煤機の有用性の检討
}

土井英史 (医療法人生長会府中病院 (大阪)), 片山恒樹 (モレーンコポレーション), 加藤敦史（環境衛生薬品）

〔目的】感染管理を考慮した污染（血液・体液などの 付着)リネン類対策は, 水溶性ランドリーバッグ（ア クアフィルムTM) を併用した熱水消毒洗濯・乾燥が有 用であることを第69回の本学会で発表した。しかし； これは多量, 少品種の既製品で中央化できるリネン類 に限られることが多く，実際の臨床では少量，多品種 の特殊な中央化できない污染りネン類も多く発生し感 染管理上問題を残していた. このような問題に対して, 厚生省ガイドライン $80^{\circ} \mathrm{C} 10$ 分間以上の条件をクリア でき，水溶性ランドリーバッグの使用も可能な小型全 自動熱水消毒洗濯乾燥機（以下, 洗濯機) が開発され た.そこで今回この洗濯機の性能と経済性を評価し, 中央化できない污染りネン類に対する有用性を検討し たので報告する.

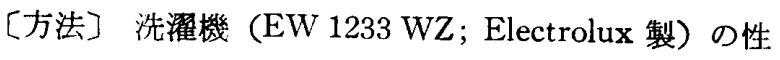
能評価として清浄度試験を実施した。清浄度試験は各 $\mathrm{n}$ 数 10 として血液污染除去試験と微生物污染除去試験 を実施した. 一方, 経済性評価は, 洗濯機本体価格及
びランニングコストを考慮し，現在臨㦿で事施してい る消毒剂価格と比較検討した。

〔結果]血液污染除去試験は, 肉眼で判断した結果, 再洗䍜を必要としない程度に清浄化されていた。また， 微生物污染除去試験は, MRSA, 大腸菌, 緑膿菌, 枯 草菌ともに全く存在しなかった。 また，経済性におい ても長期間を考慮すれば消畫剤より経済的メリットが あると考える.

[考察]中央化できない少量, 多品種で特殊な污染り ネン類の清浄化は, 従来消毒剂に依存していたが, 今 回開発された洗濯機により清浄化され実用可能である ことが確認できた.これょり院内で発生する污染りネ ン類は，水溶性ランドリーハックの併用と共に，耐熱 性素材 $\left(80^{\circ} \mathrm{C} 10\right.$ 分間以上) であれば，薬昘に依存す ることなく熱水消毒洗湌・乾燥で十分であることが結 論づけられた。つまり，この方法は医療従事者への感 染防止対策や経済性を考慮すると非常に有用であると 考えられる.

\section{8 病院内での携帯電話使用に関するアンケート結果報告}

\section{加秋 隆 (三井記念病院 MEサービス部)，小野哲章 (日本工学院専門学校),}

沢桓 (東京医科歯科大麻醉蘇生科), 渡辺 敏 (北里大臨床工学)

医療機器の近くで携帯電話を使用すると誤動作する ことがあるという報告は以前からあったが，国内のシ リンジポンプメーカから警告文が出されるまでは，そ れほど問題視されていなかった. しかし、この警告文 を発端に，いくつかの病院の ME 部門が実験を行い, その事実を確認したあたりから，マスコミ等で取り上 げられ，最近の急速な携帯電話の普及と相まって，ち ょっとした社会問題となってきている.

そこで我々は, 都内の89病院を対象に, 携帯電話と 医療機器に関するアンケートを実施した。回答数は47 で，回答率は53\%であった，具体的な質問ならびに回 答は以下のようであった。

I，院内における携帯電話の使用についてどのように していますか.

1. 全面禁止している：11（23.4\%)

2. 医用室（病室, 外来, 透析室, 検查室など）はすべ て禁止している：3(6.4\%)

3. 病室内のみ禁止している : 4 (8.5\%)
4. 医療機器を使用している病室内のみ禁止している： $2(4.3 \%)$

5. 医療機器からある距離以内には近づけないように 指導している : $2(4.3 \%)$

6. 制限していない: $17(36.2 \%)$

7. その他: $7(14.9 \%)$ 8. 無回答 : 1 (2.1\%)

II. 使用者, 操作者, 患者に対する教育方法について (複数解答可).

1. 患者に対して使用方法についてのパンフレットを 渡している：7（14.9\%)

2. 院内に揭示をしている: $13(27.7 \%)$

3. 医療従事者に対して教育 : $14(29.8 \%)$

4. その他: $18(38.3 \%) 5$. 無回答 : 3(6.4\%)

III. 携帯電話による医療機器の譟作動を経験したこと がありますか.

1.ない: $35(74.5 \%) 2$. 臨床経験がある：2(4.3\%)

3. 実験をしたことがある：8（17.0\%）

4. 無回答 : $2(4.3 \%)$ 